\title{
CREATION AND IMPLEMENTATION OF AN INNOVATION STRATEGY IN A KNOWLEDGE-BASED ORGANIZATION
}

\author{
Aurel Mihail ȚîȚU ${ }^{a, b^{*}}$, Alina Bianca POPc, Lucian TARNU ${ }^{a}$, Constantin OPREAN \\ ${ }^{a}$ Lucian Blaga University of Sibiu, România \\ ${ }^{b}$ Academy of Romanian Scientists, Bucharest, Romania \\ 'SC TechnoCAD SA, Baia Mare, România
}

\begin{abstract}
In the management of innovation, intellectual property rights play a key role. In this sense, this paper aims to describe a model for the creation and subsequent implementation of a strategy within a company with the field of activity in computer-aided design. The starting point of the study is the detailed analysis of the literature and conducting an exploratory and documentary research. The paper aims to create a working system with the knowledge of the organization, and also presents a series of recommendations in order to successfully implement innovative strategies in the organization. In the analysed company were identified the areas where problems could arise that require increased attention from managers. The research methodology adopted involves the use of the qualitative assessment method, observation methods, the document content analysis method and the questionnaire method. Finally, the own points of view on the approached topic are presented.
\end{abstract}

KEYWORDS: innovation, innovation management, innovation strategy, knowledge-based organization.

\section{INTRODUCTION}

In this information society, innovation management is perceived as an essential factor for the survival of organizations operating in very high global competition and in the conditions of rapid technological progress (Wright \& Filatotchev, 2007).

Market competition aims not only at excellence in performance or technical efficiency, but also at the ability to develop systematic processes through the production and application of knowledge. Therefore, both internal and external actors show an influence on the company's investments in research and development (Țîțu \& Oprean, 2015; Siegel \& Wessner, 2007).

Peter Drucker stated that "every organization - not just business - needs a core competency: innovation."

Schumpeter in 1934 defined innovation as the commercial or industrial application of something new, a new product, a process or a method of production, a new market or sources of supply, a new form of commercial business or financial organization (Croitoru \& Schumpeter, 2012).

The phrase "Research-Development and Innovation" (RDI) presents innovation as the last sequence of the cycle of activities carried out systematically to increase the amount of knowledge and their use in various fields of activity (Popescu, 2016; Săvescu \& Budală, 2008).

Katz, Preez and Schutte (2010) and Teece (2010) present the innovation strategy as:

${ }^{*}$ Corresponding author. E-mail address: mihail.titu@ulbsibiu.ro 
- an incremental, functional and predetermined plan governing the allocation of resources to different types of innovations to achieve a company's overall corporate strategic objectives, and - a decisionmaking framework to guide a company as to when and how it should leave selectively the past and / or change their corporate strategy and goals to focus on the business of the future.

According to Strecker (2009), the innovation strategy represents the sum of the strategic choices that a company makes regarding its innovation activity.

The objectives of innovation are not included but only the means. The innovation strategy is considered a firm and multifunctional meta-strategy (Durst \& Gueldenberg, 2012; Ricceri, 2008).

The current paper aims to describe the strategies used by a knowledge-based technology company as well as a model for the creation and subsequent implementation of an innovation strategy.

\section{RESEARCH METHODOLOGY}

The research methodology adopted to conduct this study involves the use of the qualitative assessment method, the observation methods, the method of analysing the content of the document and the method of the questionnaire.

\section{APPROACHING AN INNOVATION STRATEGY IN A KNOWLEDGE-BASED TECHNOLOGY ORGANIZATION}

In a technology-based knowledge-based organization, the innovation strategy as a system of working with innovation in the enterprise is evolving. It is necessary to properly choose the structural elements of the innovation strategy model, at the time of its creation, in order to highlight the importance of innovation in the organization.

According to Jakubíková (2008), the process of creating an innovation strategy is a complex one with six main parts:

- a defining vision and mission of the company;

- identifying strategic objectives;

- detailed analysis of the business environment (internal and external);

- strategy formulation;

- implementation of the strategy and

- subsequent evaluation associated with the control.

The innovation strategy is a conglomeration of strategic decisions on the basis of which innovative activities within the organization are managed and carried out. A successful innovation strategy needs to have several options to reflect:

- current and future developments;

- long-term effects given the relevant factors acting on the business;

- time factor.

The innovation strategy needs to be implemented in order to ensure all available resources. In order to support innovation, the organization must ensure both the efficient collection and exchange of information and knowledge.

When developing the innovation strategy, top management must perform an analysis of the internal and external environment, as well as an analysis of innovative planning and design.

The organization must know its scientific and technical capabilities, its competition, as well as Before creating an innovation strategy in the company, it is necessary to perform an audit of the current situation.

This audit includes identifying and analysing human potential, competitors, partner needs and business customers in order to create innovation. 
Methods that can be used to analyse the initial position of the organization can be in particular the forecasting method, conceptual methodological tools (SWOT analysis, BCG matrix, producttechnology matrix, project risk map, SPACE analysis STEEP analysis, Porter analysis) and innovative graphs (S-curve method, J-curve method, "gap analysis" method).

The analysis of the internal environment includes the creation of innovation capacity, the mapping of innovation potential, and the identification of the current level of use of innovation capacity and specification requirements.

The capacity for innovation consists of the amount of knowledge, experience, resources, assets and managerial skills and business skills available.

The key element is the formulation of the innovation strategy. At this stage, different variants of the innovation strategy are generated, their analysis and evaluation according to the established rules and criteria.

\section{CULTURE OF INNOVATION AND ORGANIZATION FOR INNOVATION}

The company in which the case study on the innovation strategy was conducted is a technological, knowledge-based one.

Innovation is integrated into the company's overall strategy. The dissemination of the innovation strategy is carried out by periodically updating the web-site, by updating the database of potential collaborators in order to identify the target partners for technology transfer and / or potential collaborators. At the same time, the aim is to identify the tools to stimulate innovation and technology transfer: funding sources, market research, databases, etc. (Pop \&Țîțu, 2018).

The activity of the company's departments is based on the flexibility of the teams, both in terms of approaching various types of projects and in relation to the integration of new services.

The organization's strategy aims to ensure a sustained pace of development of the company, improving the quality of products and services made to maintain a high degree of customer satisfaction.

Specifically, innovation projects involve:

- the realization of products and services at a competitive quality;

- development of research and development and innovation activities based on collaborations with private companies and business model innovation.

The sustainability of innovation in the analysed organization is guaranteed by the human resource that requires a competent staff, passionate and trained in overcoming obstacles, with an attitude directed towards lifelong learning. At the same time, top management is oriented towards innovation.

The capacity for innovation seen from the outside is one that can always be improved, in terms of better organization of the organizational structure and more precisely the clear definition of the roles of each person in a team, and in terms of increasing specialization and improving human capital.

A formal system for generating and evaluating ideas is implemented within the company in order to receive feedback from employees.

The company has a high-performance scientific and technical infrastructure to achieve the company's established objectives.

Periodically, the data about the clients are analysed in order to follow if they are satisfied with the quality of the delivered services and are interested in maintaining or improving the quality.

At the same time, it is worth mentioning the phenomenon of global competition facing the company: the increasingly strong entry into the market of companies with a similar profile that try to win and convince potential customers by practicing more modest prices and rates.

Classified as a potential threat, it requires a focus on high value-added services and / or the expansion of activities.

The company has a competitive advantage over the competition through superior products and services offered to customers. The role of innovation in this advantage is manifested by the technologies and equipment owned by the company. An analysis of the competitive advantage is presented in Table 1. 


Table 1. Map of competitive advantage
\begin{tabular}{|l|l|}
\hline \multicolumn{1}{|c|}{ Strategy and rivalry } \\
\hline+ & Modern infrastructure for RDI activities and technology transfer \\
\hline- & High costs associated with the operation of the technological infrastructure \\
\hline A & Market competition represented by low-cost companies \\
\hline O & Orientation of the industrial sector towards the development of skills in innovation \\
\hline \\
\hline+ & The existence of highly qualified human resources with multidisciplinary skills generating flexibility \\
\hline- & Existence of areas of activity with development potential, including through innovation \\
\hline A & Staff turnover \\
\hline O & Reduced exploitation of IP potential (patents, copyrights) \\
\hline \multicolumn{2}{|}{ Application conditions } \\
\hline+ & The market demands specialists \\
\hline- & - \\
\hline A & Budgetary constraints induced by changes in labour and tax legislation \\
\hline O & $\begin{array}{l}\text { The possibility of developing the business environment; and increasing the interest of foreign } \\
\text { companies in collaborations }\end{array}$ \\
\hline & \multicolumn{2}{|c|}{ Support outside the company } \\
\hline+ & Existence of partnerships and good collaboration with academia and public institutions \\
\hline- & Insufficient funding of the RDI sector from both public and private sources \\
\hline A & Possible global crisis phenomena \\
\hline O & Legislative instability \\
\hline
\end{tabular}

Source: Analysis of the research team

The competitive advantage gives the viability and competitiveness of the company in the long run. In order to identify in an effective way how the external environment can influence the business, a diagram was drawn up that includes for analysis the following factors from the external environment:

- Socio-cultural (socio-cultural);

- Technological;

- Economic (economic);

- Politic (political).

Table 2 presents this diagram with the influences manifested on the company in terms of establishing a goal of progress that involves entering new markets with the services offered.

Table 2. PESTEL map

\begin{tabular}{|c|c|c|}
\hline Political factors & Economic factors & Social factors \\
\hline $\begin{array}{c}\text { Government strategies } \\
\text { International context }\end{array}$ & $\begin{array}{c}\text { Inflation } \\
\text { Trends in market evolution } \\
\text { Customer behaviour } \\
\text { Human resource costs }\end{array}$ & $\begin{array}{c}\text { Attitudes and opinions of customers } \\
\text { How informed are the customers } \\
\text { The attractiveness of the field of activity }\end{array}$ \\
\hline $\begin{array}{c}\text { Technological factors } \\
\text { Ecological / ethical factors } \\
\text { that lead to the improvement } \\
\text { of the design process } \\
\text { Information and } \\
\text { communication technology }\end{array}$ & $\begin{array}{c}\text { Environmental protection } \\
\text { legislation }\end{array}$ & $\begin{array}{c}\text { Legal factors } \\
\text { Equal opportunities and gender }\end{array}$ \\
$\begin{array}{c}\text { Work legislation } \\
\text { Legislation on customer protection, } \\
\text { competition or occupational safety and } \\
\text { health }\end{array}$ \\
\hline
\end{tabular}

Source: organization database

The five forces that show their pressure on the company as well as their intensity are shown in Figure 1. 


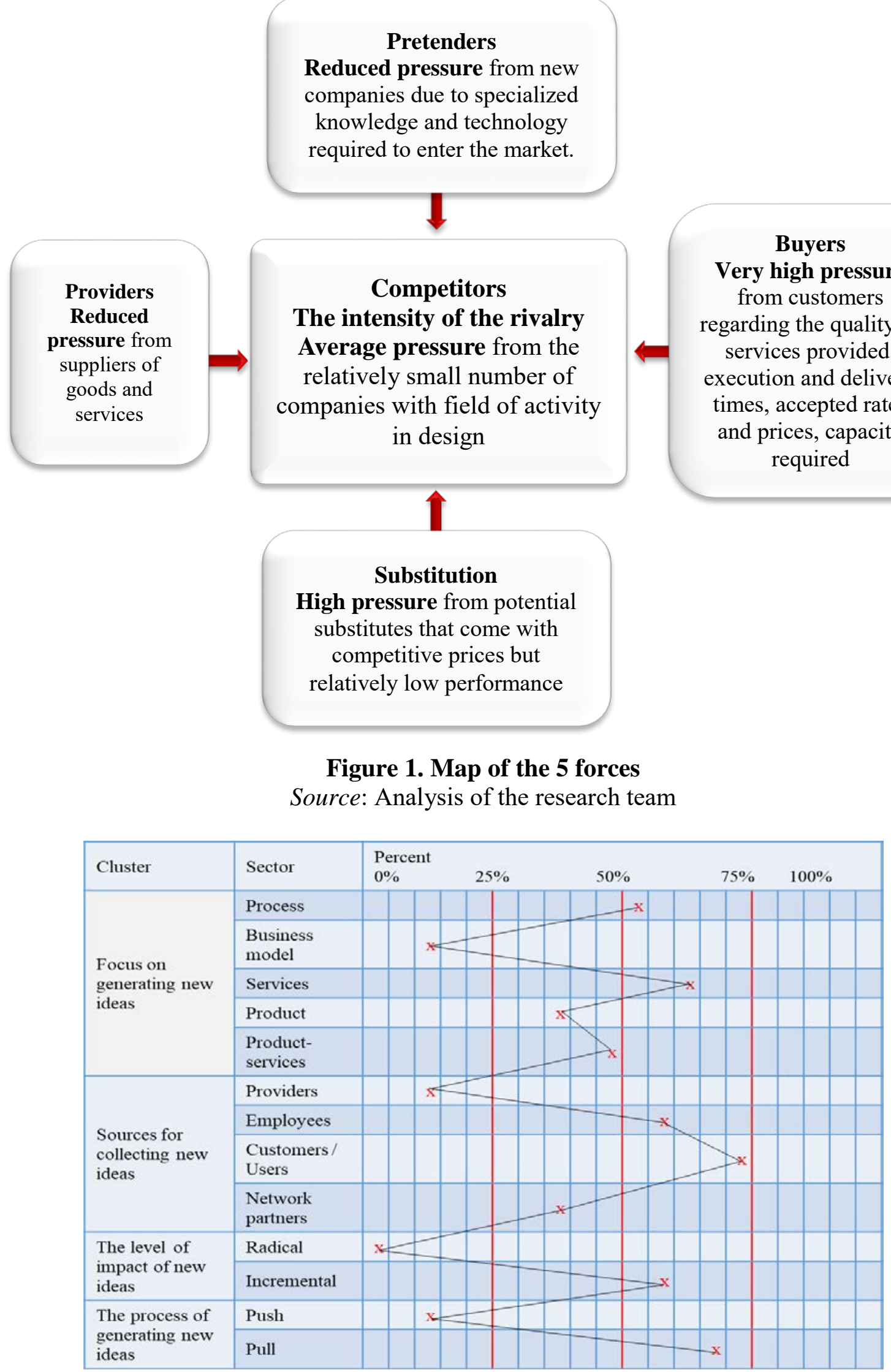

Figure 2. Map of the framework for generating innovative ideas in the company Source: Analysis of the research team 
Figure 2 shows the map of the framework for generating innovative ideas in the company.

\section{CONCLUSIONS}

Successful implementation of an innovation strategy is essential in order to avoid several potential problems such as insufficient development of an innovative program within the company.

In order to be able to successfully implement an innovation strategy, it is necessary for the organization to have:

- a sufficient basis for innovative processes;

- innovative capacity;

- innovative resources;

- information flows.

Another important aspect is that management must focus its attention on the detailed analysis of the current business situation and understand the role of technology in implementing the innovation strategy.

In order to be able to establish the evaluation system and a set of guidance rules as correctly as possible, it is imperative to know the innovative potential and to specify the innovative requirements correctly and clearly.

At the same time, defining the strategic objectives to be achieved by the organization in terms of innovation in the field of innovation strategy, is another risk issue.

The problem of excluding human factors from the innovation strategy process is common in many organizations.

The reason for this problem is that staff who are not involved in creating an innovation strategy:

- does not receive sufficient information regarding the innovation strategy of the objectives set in the company;

- is not very familiar with the intentions of the company's innovation activities;

- may be passive in some activities.

To counteract this problem, a regular and regular communication with employees is indicated, considering the creation of an innovative climate.

In other words, employees should be involved in creating innovative strategies, expressing their ideas, and both they and top management should explain the importance of the innovation strategy.

Staff need to be aware during the stages of implementing the innovation strategy.

The model innovation strategy presented provides information to staff on the following issues:

- the place to which the company is heading with innovations;

- what motivates employees;

- what is the meaning of employee work.

In other words, it can be concluded that at present, organizations aim to ensure their competitiveness through innovation.

The model of innovation strategy proposed in this paper highlights the perspectives on the analysis of the company's internal environment and the field of strategy formulation.

\section{REFERENCES}

Croitoru, A. \& Schumpeter, J.A., 1934 (2008). The Theory of Economic Development: An Inquiry into Profits, Capital, Credit, Interest and the Business Cycle, translated from the German by Redvers Opie, New Brunswick (U.S.A) and London (U.K.): Transaction Publishers. In: Journal of Comparative Research in Anthropology and Sociology, 2012, Volume 3, Number 2, 137-148.

Durst, S. \& Gueldenberg, S. (2012). The meaning of intangible assets: new insights into external company succession in SMEs, Electronic Journal of Knowledge Management, 7(4), 437-446. 
Jakubíková, D. (2008). Strategický marketing Stratégie a trendy. Praha: Grada.

Katz, B. R., Preez, N. D. \& Schutte, C. S. L. (2010). Definition and role of an innovation strategy. 60-74

Pop, A. B. \& Țîțu, M. (2018). Implementation of an Integrated Management System: QualityInformation Security in an Industrial Knowledge-Based Organization. Quality Management, 19(166), 87-93.

Popescu, M. (2016). Managementul Inovării. Editura Universității Transilvania din Brașov.

Ricceri, F. (2008). Intellectual capital and knowledge management: Strategic management of knowledge resources. London: Routledge.

Săvescu, D. \& Budală A. (2008). Proprietatea intelectuală în România și unele țări din UE. Brașov: Lux Libris.

Siegel, D. S. \& Wessner, C. (2007). Universities and the Success of Entrepreneurial Ventures: Evidence from the Small Business Innovation Research Program. Paper presented at the Cornell/McGill Conference on "Institutions and Entrepreneurship".

Strecker, N. (2009). Innovation Strategy and Firm Performance: An Empirical Study of Publicly Listed Firms. Gabler Verlag.

Teece, D. J. (2010). Business models, business strategy and innovation. Long Range Plannig. 43 (23), 172-194.

Țîțu, M. \& Oprean C. (2015). Management of intangible assets in the context of knowledge based economy, Germany: Editor LAP Lambert.

Wright, M., \& Filatotchev, I. (2014). Stimulating academic entrepreneurship and technology transfer: A study of Kings College London commercialization strategies. In T. Allen \& R. O'Shea (Eds.), Building Technology Transfer within Research Universities: An Entrepreneurial Approach, 241-261. Cambridge: Cambridge University Press. doi:10.1017/CBO9781139046930.012 